MedieKultur | Journal of media and communication research | ISSN 1901-9726

Article - Theme section

\title{
Revisitation
}

\section{A trans phenomenology of the media image}

\section{Cael M. Keegan}

MedieKultur 2016, 61, 26-41

Published by SMID | Society of Media researchers In Denmark | www.smid.dk The online version of this text can be found open access at www.mediekultur.dk

\begin{abstract}
How might certain moving images move us into transgender becoming?

The recent proliferation of transgender images in the media of the Global North has been widely regarded as supporting transgender political and social equality. But do these images do justice to the complexity of transgender lives? Who are images of transgender identity made for, and whose interests do they serve? Instead of discussing media that produce a transgender object for public consumption, this essay's author is interested in theorizing a trans point of media reception for the popular image. This essay illustrates how transgender subjects might fashion their own archives of becoming through encounters with media that unintentionally support transgender embodiment as a possibility in the world. Revisiting his phenomenological encounters with the film Under the Skin and the "Milk: It Does a Body Good" ad campaign, the author analyzes how certain media objects have the unexpected power to "move" the transgender subject into becoming.
\end{abstract}


Queer objects support proximity between those who are supposed to live on parallel lines, as points that should not meet. A queer object hence makes contact possible. Or, to be more precise, a queer object would have a surface that supports such contact.

- Sara Ahmed, Queer Phenomenology: Orientations, Objects, Others. 169.

What happens, in particular if I am a transperson reaching toward that other?

Or if it is a transperson toward whom I reach?

- Gayle Salamon, Assuming a Body: Transgender and Rhetorics of Materiality. 55.

To revisit the question of gender through media: Such a project requires nuanced attention to how gender is simultaneously the cultural material of mediated narrativity and its lived result. In this essay, I assess the current inadequacy of theories for transgender media reception, combining cultural studies and autoethnographic methodologies with phenomenology and transgender studies to generate new criteria for determining what constitutes a "trans" encounter with the moving image. I then illustrate through two first-hand accounts how unanticipated and transformative engagements with media images can aid transgender subjects in exploring the shape of our subjectivities, which exceed the dominant narratives imposed on us by journalism, medicine, and psychology. My commitment here to formal experimentation and to resistant readings of media not generally considered to be "about" transgender identity is especially inspired by Susan Stryker's "My Words to Victor Frankenstein above the Village of Chamounix: Performing Transgender Rage" in which she combines literary analysis, poetry, and autoethnography in an exploration of her affective sympathy with the monster in Mary Shelley's Frankenstein. Like Stryker's essay and the monster's body, my work below is pieced together from parts, methodologically referencing the "seams and sutures" (Stryker, 2008, p. 227) that, through a gathered archive of media objects, I continually revisit and confront within myself.

As a transgender person, I have always been fascinated with the moment of intersection between media aesthetics and my own gendered affect, scouring popular media for texts that appear to make room for my experience and embodied knowledge. Long before I had developed conscious trans and male identifications, I sought out images that seemed to offer new ways of imagining or becoming a gender in the world. As Sara Ahmed theorizes in Queer Phenomenology, certain objects-she names them queer objects-can make cognizable a touching of bodies or lives that should not meet. What makes an object "queer" is the manner in which it creates an opportunity for subjects to deviate from their predetermined phenomenological paths - to choose another "way." Taking up Ahmed's claim, I might theorize a trans object as offering the subject a normally unseen transfer between seemingly irreconcilable points (male/female, self/culture, insight/fact, present/future). A trans media object would cultivate trans consciousness by offering an aesthetic space in which the subject might feel a way forward through the closed phenomenological horizon of binary gender. Glossing Merleau-Ponty with a trans analysis, a trans media object might illustrate how gendered perception can flash and thicken across points in "the flesh of the world" (Merleau-Ponty, 1968, p. 248) that are generally considered to be "unfathomably dis- 
tant" (Marks, 2002, p.x). The parallel lines of male/female can become proximate, can meet. You can leap from one to the other, just as I always felt might be possible. To revisit my own archive of trans media objects, therefore, is also to revisit myself-in-becoming, a process of gendered self-fashioning I have pursued through media across my lifetime.

This essay revisits two media texts that have been fundamental to the growth and elaboration of my becoming-trans': one that I witnessed dozens of times on U.S. television in the early 1990s, and one I first encountered at a film screening in Ithaca, New York in 2014. While I engage Ahmed's queer theorization of phenomenology to classify these images as "trans," neither text is topically about transgender issues or directly represents transgender characters or people. I hope here to intervene in the growing identitarian discourse around transgender embodiments in popular media by pointing out that pedagogical transgender images may often be less valuable to trans people ourselves than they are to the cisgender (i.e., non-transgender) viewers for whom they are generally designed.

Instead of discussing media that produce a transgender object for public consumption, I am interested in asking what it might mean to theorize a trans point of reception for popular media. The media texts I discuss below-a U.S. ad for milk from 1992 and a British science-fiction film from 2014-speak more directly to my transgender affect, to the shape of how my own trans subjectivity feels, than many popular media "about" transgender issues (such as Boys Don't Cry, Orange Is the New Black, or Transparent) that assume a cisgender audience. I am drawn here to the moving image precisely because my transgender affect has unfolded in time, as cinematic narratives do (Platinga, 1999, p. 9). While separated by a span of twenty-one years, both textual encounters I revisit in this essay exerted a pull or "enticement" with the affective force to open perceptual possibilities in my horizon (Husserl, 2001, pp. 83-90), offering unexpected routes into transgender self-realization. My reflexive relation to these texts is what might be described as a "retrospectative," a mutually constitutive process in which the media objects I discuss work to structure my phenomenological experience even while each new textual encounter with them is simultaneously shaped by what is already "inside" myself (White, 1999, p. 197).

To echo Gayle Salamon's question above in Assuming a Body, what happens when a trans subject "reaches toward" (p. 55) an object that appears to offer a way to become something other than what is supposed to be possible? How and why does that happen? What happens during that moment when a text that is not about us or designed to permit us any identification "slips" and offers it to us nonetheless? And how is that textual object then enfolded in a process of becoming in which something that purportedly cannot exist is, nonetheless, brought closer to discourse?

\section{Through an Image}

The formalization of transgender studies as a field and its increasing interdisciplinary reach present us with a moment in which theories of transgender subjectivity are flourishing, 
contesting previous work in both the sciences and the humanities that placed transgender bodies firmly in the position of object. As a new generation of scholarship and criticism has begun to challenge the previous borders of what might be considered "trans," wellestablished work theorizing transgender media representation may require revisitation. For example, J. Halberstam's In a Queer Time and Place: Transgender Bodies, Subcultural Lives contains a chapter, "The Transgender Look," which has been considered over the past decade the primary theorization of transgender film aesthetics. Halberstam uses a close reading of Boys Don't Cry to intervene in Laura Mulvey's (1990, pp. 28-40) classic feminist analysis of film reception in which the implied cinematic viewer is always male and the scopophilic object is always female: a structuralist argument that reifies binary genders and makes no room for a transgender viewer.

Halberstam asserts that certain deployments of the "transgender look," as in Boys Don't Cry, accomplish a gaze "divided within itself" $(2005$, p. 88) — often achieved by the doubling of characters or the "hijacking" (p. 83) of gendered shot/reverse shot sequences-that permits "us to look with the transgender character, rather than at him" (p. 78). Audience members experience the narrative "as if" they were transgender, a subjunctive pedagogy aimed at allowing viewers to experience how it might feel to be trans. However, the point of reception is still assumed to be fundamentally different from the transgender object: Spectators can adopt the transgender gaze "only provisionally" (p. 86). We look "with," not through, the image. While Halberstam successfully illustrates the shortsightedness of dominant psychoanalytic and feminist film criticism that does not acknowledge the existence of queer and/or trans viewers, his theory of the transgender gaze repeats the same problematic in Mulvey's formulation -it does not theorize a transgender spectator.

Rather than thinking about how cisgender audiences might experience a prosthetic transgender gaze, I am invested here in exploring how trans subjects ourselves might interact with popular media texts to build phenomenologies of the self. Despite the growing number of transgender images in our popular media, we are left with theories of reception that deny, at their base, the existence of trans people as image consumers. Reception theories that assume a gendered "gaze" have been insufficient precisely because (as the existence of transgender subjectivity shows us) assigned categorical gender, even ideological socialization as an assigned gender, cannot necessarily determine how a subject engages with an image.

In revisiting my own relation to popular media texts that have sustained my trans becoming, I turn to Lucas Cassidy Crawford's concept of "aesthetic transgendering" (2014, p. 483) as one potential path toward a theory of trans image reception. Crawford moves us beyond a consideration of the transgender object by conceiving a reflexive methodology, enacted by trans subjects, that reveals how "trans" is always-already present in and haunts public spaces and discourses. Crawford builds this theory around an analysis of the High Line Park's nearly-erased history of transgender sex work, mixing together formal architectural analysis, his own poetry, and autoethnographic accounts of his experiences encountering the High Line as a transgender person. Crawford describes aesthetic transgendering as "a 
creative making of relations and bodies that doesn't merely occur in but occurs with public structures," stating that "[t]ransgender embodiment is poetic and architectural work, inasmuch as it is creative, spatial, transformative, discursive, and a matter of design" (pp. 483-4). For Crawford, "trans" is less a quality of identitarian being and more a way of creating or finding forms of meaning that allow transgender phenomena to extend into the world.

This essay follows Crawford's recipe for transgendering the aesthetics of public architecture by treating popular images as public spaces in the cultural imaginary. Media images are a sort of public cultural architecture through which we learn about our bodies' power to signify. We are educated in how to occupy our bodies, how far our bodies might extend and toward which objects we should extend them, through a host of collectively-experienced popular images and media narratives. Aesthetic transgendering does not simply gather together images of transgender identities but, instead, reveals how trans phenomenology lies, embedded and unacknowledged, in the architecture of culture itself. As such, it provides a wider range of strategies for bringing "trans" into intelligibility than classical aesthetics may allow.

Trans phenomena share a troubled relationship with the mechanics of sight and seeing. Since gender transition is a temporal process that often mixes and/or erases the visible markers of sex, it has proven difficult to represent the complexity of transgender embodiment in visual media, such as photography (Prosser, 1998, p. 209). Rather than seeking realist representations of transgender bodies that display the "truth" of their difference, aesthetic transgendering looks for moments of phenomenological encounter that sustain transgender poiesis: an extension of transgender becoming. A public structure is "transgendered" by the praxis of this theory to the extent that it can retrospectatively offer a conduit for transgender historicization or transgender world-making - to the extent that "trans" might reach through it to us or to the extent that trans subjects may reach out to it as a surface for becoming. Such a "thick relation" (Thick Relations, 2012) with public structures, which involves a kind of temporal folding-back of the self upon its own record of perception, invites us to "re-encounter something we've seen before, but didn't yet know what the encounter could mean to us" (White, 1999, p. 214).

What sort of archive might this reaching out toward public images that sustain "trans" build? As Crawford notes, writing a theory that presumes a transgender subject, rather than a transgender object, is its own attempt to "make new reading practices" (2014, p. 496) that can unsettle how we think of the archive and what belongs in it. Crawford convincingly demonstrates how the High Line is inextricably linked to transgender labor and community -- even through the force of a violent negation. I share Crawford's interest in how "creation-and transgender as creation-occurs" (p. 483). How does one "become" trans? How did I? In a world built to deny fundamental pieces of my existence at nearly every turn, how do I do the work of re-membering myself? How do I keep becoming what I desire? To explore this, I, like Crawford, must travel "into the structures of my own transgender affect" (p. 497), an "autotheoretical" (Preciado, 2013, p. 347) praxis through which I reach 
out to myself again and again, seeking my reflection across theory, culture, and memory. In Salamon's initial question about what it might mean to "trans" the phenomenological encounter, I am both the trans person who reaches out, and I am the trans person who is reached for. I am on both sides of the "skin" of the encounter, two seemingly separate lives on parallel lines that were not supposed to meet-but did meet nonetheless.

How, then, can I see myself?

\section{Thirteen}

My problem is that I can't accept life for what it is, like it's presented to me. I feel that there is something deep and wonderful underneath it that no one has found.

- Diary of Lou Sullivan (12/12/65)

It is 1992, and I am thirteen years old, growing up in dairy country in rural Pennsylvania. I am a bright, willful child with a strong sense of justice who does not trust the received wisdom of adults. Previously a staunch tomboy, I have over the past year begun to lose this image of myself-my reflection as the not-girl I feel I am. Increasing pressure from my parents and peers to be feminine is beginning to convince me that I will have to capitulate in the struggle over my gender. I will have to figure out how to become "a girl," or at least to live convincingly as one. This is what growing up, what time passing, means.

And yet.

Often on late summer and fall mornings, a sense of some other possibility hangs just out of reach, like an open secret no one will divulge. There has to be more in life than this path forward, I am sure. There is a part of me, some part I don't understand, that refuses to accept how limited and rigid my world is. I cannot grasp why others do not seem to feel this same thing, which I cannot name.

When I think of myself years into the future, I imagine myself far, far away from this place. I do not know how to get from here to there. I prepare to bury the parts of myself that require burying. Somewhere deep inside me, rage is pooling. I have never heard the words "transgender" or "transsexual."

\section{In Waiting}

An object...is 'losable' only insofar as it is within my horizon.

- Sara Ahmed, Queer Phenomenology: Orientations, Objects, Others. 166.

All throughout 1992, a particular ad sponsored by America's Dairy Farmers and the National Dairy Board ran on television in Pennsylvania. The ad was part of the memorable "Milk: It Does a Body Good" campaign that saturated U.S. television markets during the late $1980 \mathrm{~s}$ and early 1990s. These ads targeted children and often ran on Saturday mornings. I saw this particular ad dozens of times; and, each time, I was electrified by a strange feeling of 
interpellation that I still rarely experience with other media. The ad imprinted itself in my memory. I remember it accurately over twenty years later, when YouTube makes it possible for me to revisit it again, and again. Every time I watch it, it has the same transfixing effect.

In the ad (see fig. 1), a young white boy, perhaps eleven or twelve years old, holds an open carton of milk. He is standing in front of a dark cloth backdrop. A weightlifting barbell rests on the floor behind him. He is wearing only blue gym shorts and regards himself in a floorlength mirror. Looking down at his thin body, he queries his reflection: "What girl is gonna go for me with a body like this?" His reflection instantly ages several years, shooting up in height and gaining muscle mass, still holding the milk carton. The reflection speaks back to him:

"Hang in there, Tom. I'm you two years from now, 'cause you're drinking milk and working out." Young Tom replies, "Well, I'm not changing so far." Older Tom swigs from the carton and immediately gets even older, taller, and broader. He continues: "And tomorrow that difference can show. All that protein for muscle and calcium for bones!" Young Tom interjects, slightly high-pitched and whiny: "But I'm still a skinny bench-warmer!" Older Tom swigs milk and ages again, filling out to full adult mass, thrusting his bare pectorals proudly, his deep voice resonant in the empty room: "Hey, if the sight of yourself at eighteen doesn't convince you, Tom, listen to your senior-year girlfriend."

An attractive, blonde white woman with a bare midriff enters the mirror reflection from Older Tom's left, leaning into him with seductive femininity. "Hi, Tom, I'm waiting," she says huskily - clearly a sexual invitation. Young Tom immediately begins chugging from his milk container. The reflections disappear, and Young Tom is again doubled in the mirror. The ad ends with Older Tom's voice reciting the highly-recognizable slogan, which appears in white text over the image: "Milk. It does a body good."

What draws me to revisit this text? At first glance, the ad appears to be a flat expression of ideology. It asserts a strong sense of the desirability of normative gender, mapping that desirability along a temporal line that equates the achievement of maturity with binary gender, white masculinity, heterosexuality, and a muscular, Protestant control over the body's desires and its consumption. Assuming a young cisgender and heterosexual male viewer, it seeks to initiate that viewer into a "reproductive temporality" (Halberstam, 2005, p. 4), achieved through the use of commodity. Certainly, this ad imposed a specific definition of white, middle-class success on me as a teenager. Yet, I was not the viewer this ad sought to interpellate. Its phenomenological architecture spoke to me in unintended ways that cultivated my nascent sense of transgender possibility. Revisiting the ad from the perspective of a transgendering aesthetic, it appears to me now as a "trans" object that offered a surface for my own becoming. My consciousness "reached out" toward this object because it supported an imaginative transfer between the points girl/man that my world insisted could not connect.

When I was thirteen, the boy's situation in the ad spoke very directly to my transgender affect in a manner that few other media texts did. By my early teen years, I too had begun to stare into mirrors obsessively, hoping to perceive myself in a way that felt congruent with 


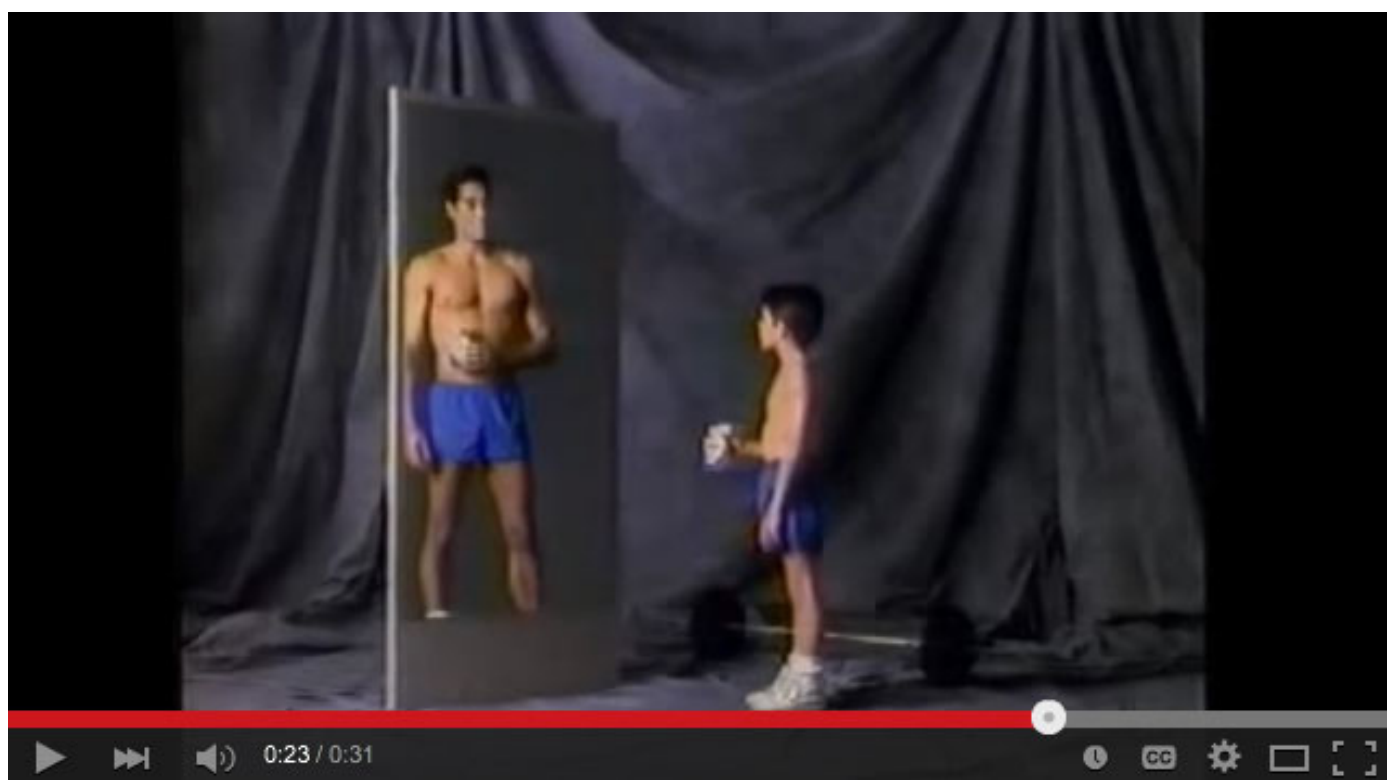

Fig. 1. Young Tom and Older Tom in the mirror.

my self-image. I sensed that my inner projection of myself did not match what I or others saw, and this was an increasing source of stress. Lacking any kind of narrative or reflection of my inner life, I scanned my environment for objects that helped me know otherwise about gender, that bolstered my innate resistance to the "straight line" (Ahmed, 2006, p. 67) in front of me. The milk ad, today a part of my phenomenological archive, put something nameless within reach that should not have been in my horizon-a possibility that became losable.

Having engaged the medical literature of transsexuality, I now understand the experience this ad captured for me- of having no correct reflection, no way to "see" what I knew was there-as gender dysphoria. The boy in the ad is also experiencing gender dysphoria. He also stares into a mirror, bemoaning what he sees and sensing that his reflection is insufficient to his gendered desires. The ad maps a path out of his situation, which leads away from dysphoria and toward the seemingly impossible end of being properly embodied. Despite its heterosexist and ableist ideology, the ad unintentionally suggests to a (white) trans masculine viewer that there is a way to exit dysphoria, something to be done that can make a person into "a man." Rather than a man simply being, the ad implies that one can also be constructed out of the proper materials. "Man" is a form of becoming that the ad suggests I might be able to enter into, that it inadvertently welcomes me into, despite itself.

When I first encountered this ad, the girlfriend's interjection-“''m waiting"-named a very real threat: Adolescent femininity loomed on the horizon, and I was under intense pressure to press myself into its shape and expectations. The inevitable outcome of my childhood was supposed to result in me looking like the girlfriend, in my becoming her. She laid in wait as a set of future expectations for gendered embodiment that felt, to me, like 
a kind of dying. But how to survive this dying, which was offered to me as the only way forward? Revisiting the ad twenty-three years later, the line "I'm waiting" has changed, now an elegy to a self that never fully happened. The unnamed she is the "me" that never quite became. She still waits to become, will never become. She is my ghost, in future tense.

I did, later in life, discover that there was, indeed, a special substance I could consume that would transform me into a man. Like the boy in the ad wishes, I can look into the mirror and see at least parts of myself reflected correctly. Revisiting this text, I now occupy both sides of the encounter, reaching across the distance of time to my younger self, insisting that becoming a certain type of man is, in fact, possible. Just like you knew it was. Rather than transforming wholly into ideal manhood, my trans phenomenology resides in the point of transfer between "girl" and "man" that the ad made discoverable for me. Always traversing this impossible leap between points, this circuit within myself, I never fully leave behind the dysphoric child, never fully arrive as the hegemonic ideal. "I'm waiting" resonates differently now. I reach out between my selves, extending with faith across this impossible space inside my life, to make contact.

\section{Thirty-five}

The face is meaning all by itself. You are you. In this sense, one can say that the face is not 'seen.' It is what cannot become a content, which your thought would embrace; it is uncontainable, it leads you beyond.

- Emmanuel Levinas, Ethics and Infinity. 86-7.

In 2014, I am an adult transgender man, teaching in a visiting position at a small liberal arts college in central New York state. It is my first job on the east coast since moving to California after completing my PhD. I am now thirty-five. Ironically, I am living only two hours away from the small town I grew up in, to which I swore I would never return.

Ghosts spring up all around, revisiting me. I drive to the nearby cities and am inundated with memories from my pre-transition life. The sense of constancy is alarming. The same buildings. The same streets. The same rolling Appalachian hills. The same graveyards.

How am I different? Am I different? My image of myself, my sense of temporality, become unmoored. I am one life in two bodies, one body with two lives.

The single-lane highway that runs through the center of the college town ends eighty-four miles south, at the precise intersection where I crashed my parents' car when I was seventeen. The front door of my apartment opens onto this same highway. I walk to work along it. My office is in a building on it.

If I were to travel those eighty-four miles south and then turn west, I would arrive at the center of my childhood landscape. No one would recognize me.

I stare in my bathroom mirror intently, practicing the memory of my faces. 


\section{Face-to-Face}

If skin is a mask, where is the self in relation to the body's surface? Deeper than the skin? Or not 'in' the flesh at all?

- Jay Prosser, Second Skins: The Body Narratives of Transsexuality. 62.

On a late spring evening in 2014, a good friend and I drove from the small college town where we both lived and taught to Ithaca, New York for a screening of Under the Skin. Loosely based on the novel of the same name by Michel Faber (2000), the film is ostensibly about an alien that is assigned a female human body in order to collect male human flesh. Expecting a science fiction thriller, what we witnessed was a brilliant meditation on the phenomenology of "assuming a body," whose implications can only be understood through social interaction. Sitting in the dark theater, I was fascinated by the alien's struggle to inhabit its (re)assigned body and to labor within a gendered cultural symbolic, which so closely reproduced the feeling and experience of "being transsexed" (Prosser, 1998, p. 67). Since witnessing Under the Skin, I have been haunted by this film-drawn to revisit it again and again in an attempt to understand my response to its shocking final imagery.

Under the Skin opens in complete darkness. A tiny white dot grows into a piercing light, and we begin to hear repetitive sounds of human language while strange orbs float and align on the screen. We are, apparently, looking out through the alien's eye, observing the construction and education of its body. This body, the film implies, has been engineered by an alien culture to labor on Earth by acquiring human flesh. Only male flesh will meet the alien culture's unexplained needs.

The alien's handlers-it is unclear whether they are aliens or men-monitor it as it drives through the Scottish countryside, luring men into its passenger seat with its attractive female body. The alien takes each of these men in succession to a completely black room in an abandoned building. Removing its clothes in a sexual seduction, the alien leads the men over a glossy black floor into which they immediately sink. Under the surface of the room, they slowly dissolve into bags of skin, their organs flushed away through a slot that collects and transfers the material elsewhere, for unknown purposes.

The alien continues its work, confusedly observing human culture, apparently devoid of any emotion until it encounters a man with a severe facial disfigurement. Though it takes this man into the black room, it unexpectedly decides to release him in apparent sympathy with his disability. ${ }^{2}$ Having broken the rules of its assignment (or possible enslavement), the alien then flees to a small town, where it is taken in by a single man. The man and the alien attempt a relationship. However, when it discovers that it cannot anatomically have sex with the man, the alien flees once again-this time into a deep, wet forest.

In the film's final few minutes, a ranger attacks the alien, attempting to rape it. The alien's skin, not designed to withstand violent handling, begins to tear open. The ranger becomes frightened and runs away. The alien, dazed and staggering, falls to its knees and slowly peels back its split human exterior, revealing underneath it a glossy skin and featureless face the color of charcoal ${ }^{3}$. The alien cradles its human face in its hands, regarding it, 
and the human face-somehow still living-regards it back (Figs. 2, 3). The ranger returns, splashing the alien with gasoline and lighting it on fire. It walks out of the forest, carrying its human skin in its arms, collapses, and dies. The film ends by suggesting that the alien will be immediately replaced by its handlers, continuing the process of flesh extraction.

To an informed viewer, there are aspects of Under the Skin that read as conscious references to trans identity. Scarlett Johansson, who plays the alien, has herself described the role as "the transformation from an 'it' to a 'she'" (Under the Skin: With Scarlett Johannson), while producer James Wilson explains the alien's narrative as becoming "infected with the sense of identity" (Under the Skin: The Hidden Lens). The alien is assigned a foreign body through which it must encounter the human world, evoking the experience of gender dysphoria (having the "wrong" body) but also gender transition (having a "new" body). The alien is not necessarily female, but its human skin appears to be: This has ramifications for the alien's work as well as its demise. The gender of the human skin assigns certain kinds of power and risk. The power is limited to serving hegemonic interests, while the risk ultimately proves deadly. The alien dies a death eerily similar to the deaths many trans women are forced to experience: sexual assault, followed by discovery that they are "not really women," followed by violent eradication.

Although it evokes a certain congruence with trans identity narratives, I would like to resist the impulse to read Under the Skin primarily as a meditation on transphobic violence. Such a reading reinforces the film's ideological message that failure to "pass" as a pre-existing gender must end in death. This reading contributes nothing new to the transgender archive, which is richly populated with tragic deaths that offer little existential possibility to trans subjects. Approaching the film through a transgendering aesthetic, I want, instead, to examine how-despite its horrifying ending-pieces of this film nonetheless support my instinctive "reach" for sources of becoming. Why do I revisit it? What sort of transport does it offer? Drawn to the moment of suspension immediately before the film's conclusion, I view the skin-shedding scene over and over. The alien's two faces, linked in an endless circle, stare wordlessly into each other's eyes, exchanging something that seems akin to compassion or, possibly, love. Something hovers there, a moment of layered relation that offers the "concretization of an imperceptible self" (Prosser, 1998, p. 211), a phenomenological knot that, for a moment, permits an impossible life into representation.

How might we read this scene of the two faces as a "trans" moment of contact between points that should not converge-a moment that bends space around itself, enfolding us in a thick relation of becoming, creating an infinite and timeless plane? In film, the facial close-up is classically deployed to provoke empathy in the audience (Platinga, 1999, p. 126), but here the structure is different: We regard each face only through the other's perspective-a "face-to-face" meeting occurring within a single subject. Levinas has discussed the face-to-face encounter as "an ultimate situation" $(1985$, p. 81$)$ in which the authority of the other's face calls one's subjectivity radically into question. For Levinas, the face-to-face is the fundamental seat of ethics at which we must confront the implacable borders of our 


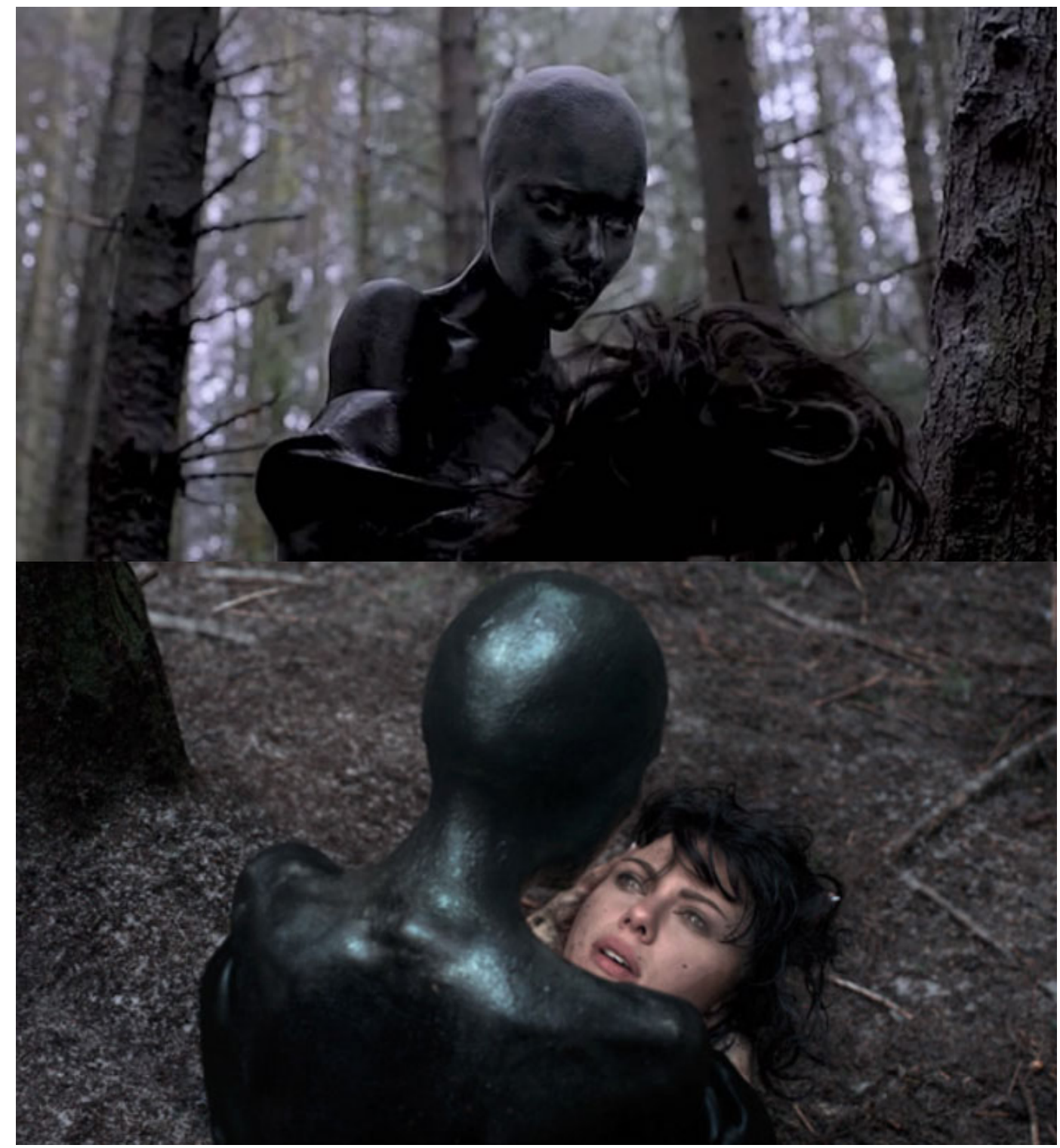

Figs. 2, 3. Under the Skin's face-to-face "alien loop."

own experience. The face-to-face meeting brings us to the edge of what is knowable, confronting us with a life entirely separate from our own-"the other"-who is still recognizable as a subject. But what if both faces in the face-to-face belong to the same life? What sort of ethical relation is enacted in this scene's "alien loop," which is an unending transit within and through the image?

In modern aesthetics, the "mirror scene" has become the crystallized symbol of the transgender subject's wounded affect (Prosser, 1998, pp. 99-134; Keegan, 2013). Over the last century, literary and visual deployments of the mirror scene have consistently depicted trans subjects as fundamentally deficient, powerless to escape the reflection of their 
despised bodies. In keeping with this tradition, Under the Skin gives us several mirror scenes in which the alien gazes at its reflection, attempting to see something unexplained. However, the climactic scene of the two faces offers a radical evolution away from the aesthetics of spoiled identity represented by these earlier mirror scenes. Instead, the face-to-face loop offers us an endless space of becoming in which singular subjectivity is forever forestalled: There is no failure to "be" because there is no "self" at which to arrive. Supplanting the mirror scene, Under the Skin's face-to-face offers the trans viewer a new "phenomenological stance" (Ratcliffe, 2012, pp. 486-7) that opens away from pathos toward a radical, internally-directed empathy.

Late in Queer Phenomenology, Sara Ahmed notes, "If a face is inverted and becomes queer or deprived of its significance, then such a deprivation would not be livable simply as loss but as the potential for new lines, or for new lines to gather as expressions that we do not know yet how to read" (p. 171). Resisting the traditional portrayal of trans self-regard as a stance of mourning, I wish, instead, to emphasize the "new lines" of self-revisitation ${ }^{4}$ that gather for me here through the image's suspended moment. The scene depicts a meetingpoint that is not supposed to meet at all, where other possibilities for becoming might momentarily arise. The gaze falls (trans-es) continuously through the eyes of the faces, a circuit with no beginning or end. Neither face is "true." Both faces are real. Which is the actual face? We see that the alien has a life of its own, but the skin also has a life of its own, its own subjective trace. There are two skins, neither of which is the "real" skin; yet, both are real. The two do not necessarily appear to be one. They live together, layered over one another, but they are not entirely integrated. They are not the same being. They are becomingtogether but not being-together identically. Where, then, is the self located?

Sitting in the dark theater with this scene for the first time, I was frozen by an instant of recognition. Something nameless inside my life moved toward signification. Yes. This. There it is. Never had a text, intentionally or otherwise, so accurately depicted for me the feeling of gender transition, the complex phenomenology of moving through the world in two faces, two skins. Revisiting myself, I regard my face in the mirror, remembering that there is another face "inside" this one, caught in the memory of my skin. Neither face is necessarily my "true" face, and both faces are real. When looking at either face, I have the reaction of surprise: There is an expected alignment that does not quite line up, that persists despite the pleasure of seeing a new face in place of the previous one. I do not see the face l expect, which was a face I did not want to see. Rather, I see a new face that is a pleasant shock, but this face is a layer over my former face, which I recall as coming before. I am both not that previous face and also not quite entirely the face I now have. The felt memory of my faces makes it impossible to simply "be" what I see in the mirror. How might one face ever regard the other? Always this ceaseless movement, always this falling in and through myself, never arriving. Always looping back, never landing.

Must I re-member myself? 


\section{Thirty-six}

If 'making sense' is necessary for success-in art and otherwise-then I think I probably
prefer failure. The task of making sense of myself, of the world I imagine,
is far less interesting to me than living in that world and in myself.

- Jules Rosskam, "Porous Cels." 558.

Trans is simultaneously everywhere-subject of contemporary cultural projectionsand nowhere-in reality absent, missing in the flesh...

- Jay Prosser, Second Skins: The Body Narratives of Transsexuality. 233.

It is 2015 , and I am thirty-six. In the past year, I have relocated again-now to the Midwest. On this new ground, previously untraveled, no ghosts appear. No hauntings arise. Without a local history or transgender peers, I struggle to find reflections of myself that might mark a path forward. All around me, blank space. Inside me, blank space.

Narratives of triumph saturate the cultural moment. Marriage equality passes. Caitlyn Jenner emerges as the new face of transgender experience. Images of transgender identity populate the U.S. media like never before-a "transgender tipping point." But what is the tip of this point tipping toward? What is the implied destination of such a movement, which promises us some kind of deliverance from a shared past? Surrounded by media about trans people, I yearn for other kinds of representation, at best incipient, at worst abandoned.

At some unmarked moment during 2015, I pass the point of five years into medical transition. Many days later, I realize the anniversary and dig into my thin archive of pretransition pictures to find the last photo taken of me before I began testosterone. A face I never entirely lived inside stares back at me, a paradox. Hoping to represent the time that has passed, I snap a new picture. This one, also, is uncanny-a stranger I welcomed in to stay but whose face I can never quite learn. I place the pictures side-by-side and am jarred by the gap in myself they create. Two separate people look back at me, a duplicated tattoo the only sign of their shared life.

I want to force this gap into representation, am desperate to see what lies there, but the photographs resist my desire. I print out the pictures -- again, side-by-side. They border, but there is no meeting. They remain resolute, discrete. I set them aside.

One morning at my desk months later, I take the pictures back up and look again. For some reason I don't then understand, something new happens. In a stroke of recognition, I fold the paper down the middle. One face now faces the other. The eyes meet in an overlap, an endless revisitation.

I hold the paper up to the light and look through. 


\section{Notes}

1 I write this essay as a white, middle-class, normatively masculine transgender man. While I have at certain points been exposed to significant precarity, my life overall has been one of relative security and intelligibility vis-a-vis other transgender people. My discussion here reflects my own experience and is not intended to assert a universal transgender archive or aesthetic.

2 Both the alien and the disfigured man fail, in inverted ways, to meet the requirements for personhood: One has no face, while the other has too many faces.

3 It cannot go without mention here that the inside skin of the alien is black. Its body is literally a "black skin" with a "white mask" - an arresting high-contrast image that is also a commentary on the racial metaphors of passing, colonization, and enslavement that the film overtly references. As Halberstam notes, skin is at once "the most fragile of boundaries and the most stable of signifiers" (1995, p. 163). While the alien's human skin is easily punctured, its whiteness permits it a mobility and authority in the human world that a black skin would not. In Black Skin, White Masks, Fanon himself describes the experience of being racially interpellated in response to the cry, "Look, a Negro!" He writes, "It was no longer a question of being aware of my body in the third person but in a triple person. [...] I existed triply. [...] I was responsible at the same time for my body, for my race, for my ancestors" (p. 112). The alien's plight, one skin inside another, echoes Fanon's description of the "epidermal schema" (p. 112) of his racialized consciousness in which he is constantly reminded of an exterior whose meaning he cannot control.

4 This would be an inversion of "the look," theorized as "being-for-others," by Sartre in Being and Nothingness (1992, pp. 340-400).

\section{References}

Ahmed, S. (2006). Queer Phenomenology: Orientations, Objects, Others. Durham: Duke UP.

Crawford, L.C. (Nov. 2014). A transgender poetics of the High Line Park. Transgender Studies Quarterly, 1(4), 482-500.

Faber, M. (2000). Under the Skin: A Novel. New York: Harcourt, Inc.

Fanon, F. (1967). Black Skin, White Masks. New York: Grove P, Inc.

Halberstam, J. (2005). In a Queer Time and Place: Transgender Bodies, Subcultural Lives. New York: NYU P.

Halberstam, J. (1995). Skin Shows: Gothic Horror and the Technology of Monsters. Durham: Duke UP.

Husserl, E. (2001). Analyses Concerning Passive and Active Synthesis: Lectures on Transcendental Logic. Dordrecht: Springer Science and Business Media.

Keegan, C.M. (Spring 2013). Moving bodies: Sympathetic migrations in transgender narrativity. Genders, 57. Retrieved Aug. 7, 2015 from https://web.archive.org/web/20140228181822/http://www.genders.org/ g57/g57_keegan.html.

Levinas, E. (1985). Ethics and Infinity. Pittsburgh: Duquesne UP.

Levinas, E. (1969). Totality and Infinity: An Essay on Exteriority. Pittsburgh: Duquesne UP.

Marks, L. (2002). Touch: Sensuous Theory and Multisensory Media. Minneapolis: U of Minnesota P.

Milk boy in the mirror ad from 1992. Retrieved Oct. 3, 2015 from https://www.youtube.com/watch?v= 0G6)ymgFusw

Mulvey, L. (1990). Visual pleasure and narrative cinema. In P. Erens (Ed.), Issues in Feminist Film Criticism (pp. 28-40). Bloomington: Indiana UP.

Platinga, Carl. (1999). Moving Viewers: American Film and the Spectator's Experience. Berkeley: $U$ of California P.

Merleau-Ponty, M. (1968). The Visible and Invisible. Evanston: The U of Nebraska P. 
Preciado, P.B. (2013). Testo Junkie: Sex, Drugs, and Biopolitics in the Pharmacopornographic Era. New York: The Feminist $P$ at CUNY.

Prosser, J. (1998). Second Skins: The Body Narratives of Transsexuality. New York: Columbia UP.

Ratcliffe, M. (Oct. 2012). Phenomenology as a form of empathy. Inquiry, 55(5), 473-95.

Rosskam, J. (Nov. 2014). Porous cells. Transgender Studies Quarterly, 1(4), 586-9.

Salamon, G. (2010). Assuming a Body: Transgender and Rhetorics of Materiality. New York: Columbia UP.

Sartre, J.P. (1992). Being and Nothingness: A Phenomenological Essay on Ontology. New York: Washington

Square $P$.

Stryker, S. (2006). My words to Victor Frankenstein above the village of Chamounix: Performing transgender rage. In S. Stryker and S. Whittle (Eds.), The Transgender Studies Reader, Vol. 1. (pp. 244-56). London: Routledge.

Sullivan, L.G. Unpublished diary. Cited in S. Stryker (2008), Transgender History (p. 116). Berkeley: Seal P.

Thick Relations. (2012). Dir. Jules Rosskam. Retrieved Jan. 16, 2016 from http://www.julesrosskam.com/thickrelations/

Under the Skin (2014). Dir. Jonathan Glazer. A24 Films.

Under the Skin: The Hidden Lens (2014). A24 Films.

Under the Skin: With Scarlett Johansson (2014). A24 Films.

White, P. (1999). Uninvited: Classical Hollywood Cinema and Lesbian Representability. Bloomington: Indiana UP.

Cael M. Keegan

Assistant Professor, PhD

Women, Gender, and Sexuality Studies

Grand Valley State University

Michigan, USA

keeganc@gvsu.edu 